\title{
The Impacts of Illegal Gold Mining Toward The Implementation of Farming Rice Based on The Ecological Dimension in Merangin Regency Jambi Province
}

\author{
Erwan Wahyudi \\ Balai Pengkajian Teknologi Pertanian Jambi \\ Jambi, Indonesia \\ masbro.erwan@gmail.com
}

\author{
Firdaus \\ Balai Pengkajian Teknologi Pertanian Jambi \\ Jambi, Indonesia \\ Fird6101osa@gmail.com
}

\begin{abstract}
Merangin regency has become one of main areas in Jambi province with rampant illegal gold mining in the Rice Production areas for the last three years, giving a negative impact on the rice farming existing around the mine area. This research study aimed to identify the sustainability of farming rice based on the ecological dimension around the coal mining areas. The research was done in Merangin regency, 50 respondents as the samples were taken by proportional stratified random sampling techniques, categorized in two farmers conditions as near/inside and outside/ faraway from the illegal gold mining. In identifying the sustainability of farming ricefields used qualitative measurements by looking at its indicators. The indicator included ecological dimension such as floods in rainy season, water shortage for household purposes, air pollution, and increase of frequency disease occurring in farming rice.
\end{abstract}

Keywords-Ecological dimensions, sustainability, farming, rice and mine

\section{INTRODUCTION}

Illegal Gold mining activities in Sungai Manau District Merangin Regency has not only destroyed the environment and rice product areas but also has destroyed the "landmark" or the Country Tourism icons. The area was previously a productive ricefields being unique and distinctive because of the existence of the waterwheel and river snaking as its own tourism attraction. But now, hundreds of hectares of ricefields having productive people's property as well as beautiful nature and rivers have been destroyed yet the mining process still continues to operate without being controlled even being more rampant, according to Ir. Guntur Chair, a tour guide in Jambi. It used to be river area under the foot of Bukit Barisan, standing hundreds of watermills even old watermills. Windmills are irrigation tools for the rice fields.

The mining sector is an important segment of the extractive sector and also has environmental and catastrophic consequences if not managed properly [1]. The exploitation of natural resources through illegal gold mining has been large and has not been in accordance with operational standards for the last three years, resulting in the decline and environmental damage. The environmental changes surrounding the mines as the process of converting agricultural land into the mining area are not done right and also give negative impact for farmers who own the land surrounding the mining areas [2]. Thus, the appreciation of environment is needed to find out how big the farmers' willingness to receive some external cost from the mining party which must be given in order to improve the environment and the influenced factors [3].

Fears of environmental damage, land reduction, and lack of progress in agricultural farming system have been stated by many scientists and agricultural business practitioners since 1990. [4]; [5]; [6]; [7]; [8]; [9]. In Indonesia, the land resources conservation program has been limited on hilly farmland or landslide. While, on flatland and paddy fields, there has been no program for preserving the soil quality and fertility. Though all farmland with very intensive management but less precise can be damaged. [10] Mentions twelve factors that can lead to soil degradation and decrease soil productivity as well as reduces agricultural production sustainability systems. Research [11], empirically shown that land of rice fields in Banten and Lampung experience reduction symptoms, as seen on higher fertilizer needed to acquire the same rice results, compared to previous seasons, the layer of mud or top soil becomes more shallow, needed more frequent for watering, rice field being easily dry, and organic matter content of the land is low.

[12] Gave a strong warning as follows: scientists have found out that the devastation of land resulting in a decrease of land productivity and national food production growth rate in many countries. Degradation and damage will continue to occur by a variety of causes and consequently food shortages in many countries will be serious problems in the XXI century. Scientific American stated that the use of natural resources by a large number of population pressure and by poverty, will impact against the biodiversity and environmental quality decline, and if not prevented, then mankind will face environmental 
crisis. According to [13], sustainable farming is ecologically viable farming practices, economically profitable, and socially defensible. This research aimed to find out and analyze the impact of sustainable agriculture implementation on farming rice based on the economic dimensions surrounding the gold mine in the Merangin Regency.

\section{METHODS}

\section{A. Research Location}

The research was conducted in Merangin Regency Jambi Province. The site selection was based on the consideration of county as one of rice production areas existing in Jambi province. Besides, it is a region experiencing agricultural land conversion into gold mining without permission (PETI)

\section{B. Population, Sample and Sampling Techniques}

Selected location used as sample was Sungai Manau and Parentak by purposive sampling, i.e. interesting sampling of intentionally based on certain considerations [14]. The region chosen with consideration to be around the area of gold mining without permission (PETI) and is one of the rice producers. The number of samples used in this study was 50 respondents taken by proportional stratified random sampling techniques categorized in two farmers conditions as farmers around the area and farmers outside the area of gold mining without permission (PETI).

\section{Methods Of Data Analysis}

In identifying the sustainability of farming rice surrounding the coal mines using qualitative measurements, by looking at indicators of tarmy sustainability including ecological dimension. Sustainability index is determined in the following way:

Sustainability index $=\frac{\text { gaved score }}{\max \text { score }} \times 100 \%$

To find out the sustainable agriculture status surrounding the coal mines using sustainable agriculture category [15] as (a) index value of $0.00-25.00$ (bad/not sustainable); (b) the index value $25.01-50.00$ (less/less sustainable); (c) index value of $50.01-75.00$ (sufficient/sustainable enough), and (e) index value of $75.01-100.00($ good/very sustainable).

\section{RESULTS AND DISCUSSION}

Sustainable agricultural application based on ecological dimension was measured with four indicators in terms of floods intensity in the rainy season, water shortage for household purposes, air pollution, and frequency of disease occurring in farming rice. The result of the analysis as presented in the following Table:
Table 1 Sustainable agricultural application based on ecological dimensions surrounding PETI area and faraway PETI area in Merangin Regency

\begin{tabular}{|c|c|c|c|c|}
\hline \multirow{2}{*}{ Indicator } & \multicolumn{2}{|c|}{$\begin{array}{c}\text { Around PETI } \\
\text { Area } \\
\end{array}$} & \multicolumn{2}{|c|}{$\begin{array}{c}\text { Faraway PETI } \\
\text { Area } \\
\end{array}$} \\
\hline & Score & Index & Score & Index \\
\hline $\begin{array}{l}\text { 1.Flood in the rainy } \\
\text { season. }\end{array}$ & 1.40 & 27.33 & 3.50 & 70.50 \\
\hline $\begin{array}{l}\text { 2. Frequent lack of } \\
\text { water for household } \\
\text { purposes for the last } \\
3 \text { years. }\end{array}$ & 3.00 & 56.00 & 3.80 & 70.50 \\
\hline $\begin{array}{l}\text { 3.An increase in air } \\
\text { pollution for the last } \\
3 \text { years. }\end{array}$ & 2.00 & 35.25 & 2.25 & 44.50 \\
\hline $\begin{array}{l}\text { 4. The increase in the } \\
\text { frequency of disease } \\
\text { attacks in farming } \\
\text { rice. }\end{array}$ & 2.45 & 45.00 & 2.45 & 50.50 \\
\hline Average & 2.21 & 40.90 & 3.00 & 59.00 \\
\hline
\end{tabular}

Source: analysis of primary data, 2017

The average index value of sustainability of sustainable agricultural application based on the ecological dimensions of four indicators worth 40.90 in the surrounding PETI area and worth 59.00 faraway PETI areas. This shows that the implementation of sustainable agriculture in terms of ecological aspects surroundings the mine means less sustainable. The application of sustainable agriculture in the surrounding area due to the ongoing impact less PETI caused by the coal mining activities against the rice farming activities in Merangin Regency i.e. frequent floods in the rainy season, based on studies of sustainability index for the area surrounding the mine, the flood impact worth 27.33 resulting in less sustainable and sustainability index for the outside mine area worth 70.50 means rare floods occurance there so that sustainability index shows the areas as very sustainable.

During the dry season, wells at the research site for the last 3 years have experienced water shortage resulting community's difficulties to get water used for household purposes. Based on the research index of sustainability for surrounding and inside the PETI area worth 56.00 while the outside PETI worth 70.50 meaning rice farmers have experienced difficulty to get water. The application of sustainable agriculture around PETI for the last 3 years has also been less sustainable due to an increase in air pollution as the result of the coal mining activities. This occurs because the function of forest nearly decimated, many trees are cut down as a patron and switch function into the mining area. Forests supposed to provide many benefits to human activities are now area of causes the incidence to nature. The community should enjoy the benefits of the forest, thus, now often feel a loss of nature. Its sustainability index value in the area surrounding PETI 
worth 35.25 while for rural areas worth 44.50 PETI on site rice farmers an increase in air pollution so that sustainability index worth less sustainable.

With mining also lead to a rise in the frequency of disease attacks on rice plant, as well as the growing number of plant pests that plague crops of rice fields. So farmers are also experiencing a decline in the rice production. Sustainability index in the region around PETI worth 45.00 meaning less sustainable and worth 50.50 faraway from the mining areas regarded as quite sustainable. The application of sustainable agriculture shows that both research locations experience disease attacks in rice plant.

\section{CONCLUSION}

Sustainable implementation of agricultural level as seen from the ecology surrounding PETI area, including PETI in the category of sustainable, the sustainability index with less than 40.90 and for rural areas are still included in PETI category with an index of sustainability as sustainable enough worth 59.00. An assessment of farming is viewed from the point of ecology can be seen from the frequently occurring flood on the farmers' land for farming rice in the area surrounding PETI. PETI in different areas. The average farming rice in the surrounding areas is lower intensity of PETI flooded land compared to rural areas, as well as on PETI easily getting the right water, pollution levels and the disease attack on agricultural land managed by the farmers.

\section{REFERENCES}

[1] D. O. Boateng, F. N. Y. Codjoe and J. Ofori, "Impact of illegal small scale mining (Galamsey) on cocoa production in Atiwa district of Ghana" Int. J. Adv. Agri. Resch., Vol. 2, No. 89-99, 2014

[2] E. P. Febrianti, "Analisis Ekonomi dan Keberlanjutan Usahatani Kopi di Kawasan Hutan Kabupaten Lampung Barat”. Desertation. Universitas Gadjah Mada, 2010.
[3] www2.epa.gov, "Frequent Questions Related to Gold King Mine Response", 2015. [Online], Available: http://www2.epa.gov/goldking mine/frequentquestionsrelated-gold-king-mine-response. [Accessed 2November-2015]

[4] R. R. Hardwood, "Low input technology for sustainable agricultural system. In V.W. Ruttan and C.E. Pray (eds). Policy for Agric. Research. West View Press. Boulder, Colorado, USA, 1987

[5] H. O. Carter,. The agricultural sustainability issue : an overview and research assessment. p.115-135. Dalam E. Javier and U. Resborg (eds) : The changing dynamics of global agriculture. ISNAR. The Hague, The Netherlands, 1988.

[6] D. J., Greenland,. The sustainability of rice farming. CAB International and IRRI. CAB. Int. Wallingford, United Kingdom, 1997.

[7] L.W. Harrington,. Intermeting and measuring sustainability, issue and options. Farming for the future. MacMillan, London, 1992.

[8] M. S. Swaminathan,. Research for sustainable agricultural development in South Asia, opportunities and challenges. Seminar Prociding on Agricultural Research and Development in Bangladesh. BRRI, Gasipur-1701-Bangladesh., 1997.

[9] Suwarno and Suyamto, 1998. Agroekoteknologi sebagai dasar pembangunan sistem usaha pertanian berkelanjutan. P.235256. Prosiding Analisis Ketersediaan Sumber Daya Pangan dan Pembangunan Pertanian Berkelanjutan. Badan Litbang Pertanian. Jakarta.

[10] S. L. Tisdale, W.L. Nelson., J.D. Beaton and J.L. Havlin, Soil fertility and fertilizer. Fifth ed. McMillan Pub. Co. New York, 1993.

[11] Sumarno and U. G. Kartasasmita,. Analisis tingkat adopsi teknologi produksi padi sawah mengacu produktivitas optimal dan berkelanjutan. Laporan akhir penelitian Analisis Kebijakan Teknis. Puslitbangtan, 2011.

[12] L. R. Brown and Kane, Reassessing the earth's population carrying capacity. Full House Publishing, New York, 1997.

[13] L. A. Thrupp (ed),. New Partnerships for Sustainable Agriculture. World Resource Institute New York, pp. 136., 1996.

[14] M. Singarimbun and S. Effendi, Metode Penelitian Survai. Pustaka LP3ES Indonesia. Jakarta., 1989. 